\title{
Studies on acute toxicity of synthetic pyrethroid $\lambda$-cyhalothrin on freshwater fish Labeo rohita
}

\author{
P. D. Gadhave', R. S. Brar', H. S. Banga ${ }^{1}$ and A. Dhawan ${ }^{2}$
}

1. Department of Veterinary Pathology, College of Veterinary Science, Guru Angad Dev Veterinary and Animal Sciences University, Ludhiana-141004, Punjab, India; 2. Department of Aquaculture, College of Fisheries, Guru Angad Dev Veterinary and Animal Sciences University, Ludhiana-141004, Punjab, India.

Corresponding author: P. D. Gadhave, email: pdgadhave@gmail.com

Received: 29-10-2013, Revised: 14-11-2013, Accepted: 19-11-2013, Published online: 06-01-2014

doi: $10.14202 /$ vetworld.2014.7-9

How to cite this article: Gadhave PD, Brar RS, Banga HS and Dhawan A (2014) Studies on acute toxicity of synthetic pyrethroid $\lambda$-cyhalothrin on freshwater fish Labeo rohita, Veterinary World 7(1): 7-9.

\begin{abstract}
Aim : To study the acute toxicity of $\lambda$-cyhalothrin in freshwater fish Labeo rohita by determining the 96 hours lethal concentration $50\left(96 \mathrm{hrs} \mathrm{LC}_{50}\right)$ and behavioural patterns of exposed fish.

Materials and Methods: A total 270 fingerling size fish were used to determine the 96 hours lethal concentration 50 (96 hrs $\mathrm{LC}_{50}$ ) of $\lambda$-cyhalothrin as per the guideline of Organization for Economic Co-operation and Development (OECD) 203 except the loading density which was higher than the recommended density $1.0 \mathrm{~g} / \mathrm{l}$ to reduce the chemical loss. The fingerlings were brought from the local fish hatchery, disinfected and acclimatized for 14 days in laboratory conditions. 60 fingerlings, 10 each were divided into six plastic tubs of $35 \mathrm{~L}$ capacity with $0 \mathrm{ug} / \mathrm{L}$ (control), $10 \mathrm{ug} / \mathrm{L}$ ethanol only (vehicle control), $0.1 \mathrm{ug} / \mathrm{L}$, $1 \mathrm{ug} / \mathrm{L}, 5 \mathrm{ug} / \mathrm{L}$ and $10 \mathrm{ug} / \mathrm{L}$ of $\lambda$-cyhalothrin in $20 \mathrm{~L}$ of dechlorinated tap water. Static renewable bioassay was conducted using five selected doses in between concentrations causing 10 to $100 \%$ mortality i.e. $2 \mathrm{ug} / \mathrm{L}, 2.5 \mathrm{ug} / \mathrm{L}, 3 \mathrm{ug} / \mathrm{L}, 3.5 \mathrm{ug} / \mathrm{L}$ and $4 \mathrm{ug} / \mathrm{L}$ along with control and $4.0 \mathrm{ug} / \mathrm{L}$ of acetone only as vehicle control. Water quality parameters like temperature, $\mathrm{pH}$, total hardness and total alkalinity were measured daily. The experiment was repeated three times. Behavioural pattern and mortality was recorded periodically.
\end{abstract}

Results: The fish exposed to chemical showed erratic swimming, loss of balance, surfacing and convulsions in a dose dependent manner. $2.72 \mathrm{ug} / \mathrm{L}$ was calculated as $96 \mathrm{hrs} \mathrm{LC}_{50}$ value for $\lambda$-cyhalothrin in Labeo rohita.

Conclusions: $\lambda$-cyhalothrin was reported as highly toxic chemical for Labeo rohita producing altered behavioural pattern in dose dependent manner.

Key words: $\lambda$-cyhalothrin, fingerlings, Labeo rohita

\section{I ntroduction}

Synthetic pyrethroid insecticides are structural analogue of pyrethrins which are insecticidal compounds obtained from plants such as Chrysanthemum cinerariaefolium and Chrysanthemum cineum [1]. These compounds contribute around $30 \%$ of global consumption of pesticides in agriculture [2]. The synthetic pyrethroids used for agricultural purpose can contaminate the water bodies during rainy season and were detected ranging from $0.100-1.000 \mu \mathrm{g} / \mathrm{l}$ in rain water collected from Hisar, India [3]. $\lambda$-cyhalothrin is one of the synthetic pyrethroid commercially available under different brand names such as Warrior, Karate, Matador etc. The $96 \mathrm{hrs} \mathrm{LC}_{50}$ of $\lambda$-cyhalothrin in mosquito fish was $1.107 \mathrm{ug} / \mathrm{L}$ [4], under laboratory conditions. On rice field normal application of this insecticide resulted in $100 \%$ mortality of mosquito fish [5]. Therefore it is important to know the acute toxicity of this compound in freshwater fish. Labeo rohita an Indian major carp is one of the most preferable freshwater fish contributing about $35 \%$ of the total carp

Copyright: The authors. This article is an open access article licensed under the terms of the Creative Commons Attribution License (http://creativecommons.org/licenses/by/2.0) which permits unrestricted use, distribution and reproduction in any medium, provided the work is properly cited. production in India, last decade [6]. Information regarding the $96 \mathrm{hrs} \mathrm{LC}_{50}$ toxicity of $\lambda$-cyhalothrin in Labeo rohita has not been reported till date. Hence, the present study was undertaken to determine the acute toxicity of $\lambda$-cyhalothrin in Labeo rohita fingerlings using static renewable bioassay.

\section{Materials and Methods}

Ethical approval: The experimental protocol was approved by the Institutional Animal Ethics Committee (IAEC).

OECD Guidelines: $96 \mathrm{hrs} \mathrm{LC}_{50}$ of $\lambda$-cyhalothrin was determined as per the guidelines of Organization for Economic Co-operation and Development (OECD) 203 except the loading density which was higher than the recommended density $1.0 \mathrm{~g} / \mathrm{l}$ to reduce the chemical loss.

Chemicals used: Analytical grade $\lambda$-cyhalothrin, obtained from Sigma-Aldrich, USA. Analytical grade acetone and potassium permanganate obtained from SD Fine-Chem, Mumbai, India.

Fish: Healthy Labeo rohita fingerlings of length $7.1 \pm$ $1.54 \mathrm{~cm}$ and weight $8.3 \pm 1.83 \mathrm{~g}$ were obtained from Nanokey fish seed hatchery, Nanokey, district Patiala, 
Table-1. Percent mortality observed during range finding assay

\begin{tabular}{lcc}
\hline$\lambda$ cyhalothrin & $\begin{array}{c}\text { No. animals } \\
\text { exposed }\end{array}$ & $\begin{array}{c}\text { Mortality \% } \\
\text { after 96hrs }\end{array}$ \\
\hline Control $(0 \mathrm{ug} / \mathrm{L})$ & 10 & 0 \\
Vehicle control $(0 \mathrm{ug} / \mathrm{L})$ & 10 & 0 \\
$0.1 \mathrm{ug} / \mathrm{L}$ & 10 & 0 \\
$1 \mathrm{ug} / \mathrm{L}$ & 10 & 10 \\
$5 \mathrm{ug} / \mathrm{L}$ & 10 & 100 \\
$10 \mathrm{ug} / \mathrm{L}$ & 10 & 100 \\
\hline
\end{tabular}

Table-2. Percent mortality observed during static renewable bioassay

\begin{tabular}{lcccc}
\hline$\lambda$ cyhalothrin & $\begin{array}{c}\text { No. animals } \\
\text { exposed }\end{array}$ & \multicolumn{2}{c}{ Mortality \% after 96hrs } \\
\hline Control $(0 \mathrm{ug} / \mathrm{l})$ & 10 & 0 & 0 & 0 \\
Vehicle control $(0 \mathrm{ug} / \mathrm{l})$ & 10 & 0 & 0 & 0 \\
$2 \mathrm{ug} / \mathrm{L}$ & 10 & 20 & 10 & 20 \\
$2.5 \mathrm{ug} / \mathrm{L}$ & 10 & 40 & 30 & 40 \\
$3 \mathrm{ug} / \mathrm{L}$ & 10 & 60 & 50 & 50 \\
$3.5 \mathrm{ug} / \mathrm{L}$ & 10 & 90 & 70 & 80 \\
$4 \mathrm{ug} / \mathrm{L}$ & 10 & 100 & 100 & 100 \\
\hline
\end{tabular}

Table-3. 95\% Confidence limits for $\lambda$-cyhalothrin concentrations

\begin{tabular}{lclcc}
\hline Sr. No. & Probability & \multicolumn{4}{l}{ 95\% Confidence Limits for $\lambda$ cyhalothrin concentrations ${ }^{\mathbf{a}}$} \\
\cline { 3 - 5 } & & Estimate & Lower B ound & Upper Bound \\
\hline 1 & 0.5 & $2.609(0.417)$ & $2.266(0.355)$ & $2.904(0.463)$ \\
2 & 0.5 & $2.874(0.459)$ & $2.549(0.406)$ & $3.211(0.507)$ \\
3 & 0.5 & $2.697(0.431)$ & $2.318(0.365)$ & $3.038(0.483)$ \\
\hline
\end{tabular}

a. Logarithm with base10 is given in parenthesis

Punjab.

Pre-treatment and acclimatization: The fish were treated with $500 \mathrm{mg} / \mathrm{L}$ potassium permanganate for one minute to reduce the microbial load, if any, on arrival in laboratory. The fish were fed with commercially available feed @ $2 \%$ of initial biomass twice a day during the period of acclimatization for fourteen days, in 300 litre capacity plastic water tank with continuous supply of air from compressors. The light and dark periods of $12 \mathrm{hrs}$ each were maintained during the experiment.

Experimental procedure: Feeding was stopped $24 \mathrm{hrs}$ before the commencement of the toxicity test to reduce the organic load and no feed was given to fish during range finding and static renewable bioassays. The review of literature revealed the acute toxicity of $\lambda$ cyhalothrin ranges from 0.1 to $10 \mathrm{ug} / \mathrm{L}$ in different fish species therefore to redefine and for confirmation, the range finding assay was carried out using 60 fingerlings, 10 each in six plastic tubs of 35 L capacity containing $20 \mathrm{~L}$ of dechlorinated tap water. Two controls were used with only water and highest concentration of ethanol i. e. $10 \mathrm{ug} / \mathrm{L}$ in water. Treatment groups included $0.1 \mathrm{ug} / \mathrm{L}, 1 \mathrm{ug} / \mathrm{L}, 5 \mathrm{ug} / \mathrm{L}$ and $10 \mathrm{ug} / \mathrm{L}$ of $\lambda$-cyhalothrin in water. To keep the chemical concentration constant, water was changed every 24 hrs. Five concentrations within the acute toxicity range i.e. $2 \mathrm{ug} / \mathrm{L}, 2.5 \mathrm{ug} / \mathrm{L}, 3 \mathrm{ug} / \mathrm{L}, 3.5 \mathrm{ug} / \mathrm{L}$ and $4 \mathrm{ug} / \mathrm{L}$ as per range finding assay were chosen to calculate $96 \mathrm{hrs}$ $\mathrm{LC}_{50}$ of $\lambda$-cyhalothrin. The experiment was conducted three times along with $4.0 \mathrm{ug} / \mathrm{L}$ of acetone only as vehicle control and normal control. The water quality was determined as per the standard protocols [7]. Every water tank was supplied with continuous aeration. Aeration was stopped only during water exchange and dosing. Mortality was recorded for every 24 hrs till 96 hrs. The behavioural patterns of exposed fish were observed at initial 1-5 hrs followed by every $12 \mathrm{hrs}$ throughout the experiments and compared with control fish.

Statistical analysis: The mortality percentage values observed after $96 \mathrm{hrs}$ were subject to probit analysis using computerized program SPSS 16.0 Inc. USA to determine $96 \mathrm{hrs} \mathrm{LC}_{50}$ along with confidential limits (upper and lower).

\section{Results}

The water quality parameters during the experiment were as follows: $\mathrm{pH}(7.36 \pm 0.07)$, temperature $(28.57 \pm$ $\left.0.55^{\circ} \mathrm{C}\right)$, total hardness $(284.12 \pm 3.13 \mathrm{mg} / \mathrm{l})$ and total alkalinity $(281 \pm 4.25 \mathrm{mg} / \mathrm{l})$ and dissolved oxygen $(8.4$ $\pm 0.34 \mathrm{mg} / \mathrm{l})$ during the experiment. $10 \%$ and $100 \%$ mortality was observed at 1 and $5 \mathrm{ug} / \mathrm{L}$ (Table-1). The doses for the static renewable bioassay were chosen on the basis of this result. Two doses below and two above mean dose of probable $50 \%$ mortality (i.e. $2.5 \mathrm{ug} / \mathrm{L}$ ) were selected. The results of static renewable bioassay after $96 \mathrm{hrs}$ revealed $30 \%$ to $40 \%$ at $2.5 \mathrm{ug} / \mathrm{L}$ while 50 to $60 \%$ mortality at $3 \mathrm{ug} / \mathrm{L}$ (Table-2). The probable values of $96 \mathrm{hrs} \mathrm{LC}_{50}$ were in between 2.5-3 ug/L concentrations. Probit analysis method was applied to 96 hrs mortality percentage values of different experimental sets to calculate the probable values of 96 hrs $\mathrm{LC}_{50}$ for each set using computerized software SPSS 16.0 Inc. USA. The probable value of $\mathrm{LC}_{50}$ for the first set was $2.609 \mathrm{ug} / \mathrm{L}$ while others set were 2.874 $\mathrm{ug} / \mathrm{L}$ and 2.697 ug/L (Table-3). The mean of these three value $2.72 \mathrm{ug} / \mathrm{L}$ was taken as the true $96 \mathrm{hrs} \mathrm{LC}_{50}$ of $\lambda$ cyhalothrin in Labeo rohita fingerlings. The behavioural changes significantly increased in exposed fish as compared to control fish in dose dependent manner during the experiment. These changes included erratic swimming, loss of balance, surfacing and convulsions.

\section{Discussion}

$\lambda$-cyhalothrin is highly toxic to many fish and aquatic invertebrate species [8]. The findings of the experiment were congruent with the report of $96 \mathrm{hrs}$ $\mathrm{LC}_{50}$ of $\lambda$-cyhalothrin in Clarias batrachus as $5 \mathrm{ug} / \mathrm{L}$ and behavioural changes during the acute exposure such as change in color of skin, hyperactivity, loss of balance, rapid swimming, increased surfacing activity, 
enhanced rate of opercular activity, as well as prominent rates of convulsions in fish in a dose dependant manner [9].

Previous studies found varying values for the 96 hrs $\mathrm{LC}_{50}$ of $\lambda$-cyhalothrin probably because of temperature, $\mathrm{pH}$, and other water quality parameters effects the toxicity of $\lambda$-cyhalothrin besides, time of exposure, method of determination, chemical purity, age and species of fish was also taken into consideration. The present investigation reported the higher $\mathrm{LC}_{50}$ value as compared to previous researchers. However, the present $\mathrm{LC}_{50}$ value was less than that of $\mathrm{LC}_{50}$ values reported in Clarias batrachus as $5 \mathrm{ug} / \mathrm{L}$ [9] and in Channa punctatus as $7.92 \mathrm{ug} / \mathrm{L}$ [10]. This could probably because of higher temperature and fingerling sized rohu fish were used in this study. This can be correlated with report that pyrethroid compounds were more toxic at lower temperature [11] which might be due to the increased sensitivity of an organism's sodium channels at low temperatures [12].

It has been well documented that the toxicity of pyrethroids may decrease in the presence of suspended solids in water [13] under field conditions. It may be possible that the low temperature of the water bodies after the monsoon period and winter months may cause events of mortalities in aquaculture if these pesticides used carelessly since $\mathrm{LC}_{50}$ values are very low for fish. Therefore, more precautions should be taken while using these pyrethroid compound products during lower temperature periods. There was no information regarding $\lambda$-cyhalothrin toxicity at multiple temperatures in fish. Further research is required to assess possible ecological risk of this chemical at different temperature and water quality parameters. The information produced by toxicity test of active ingredient should be correlated with toxicity test of components of different pyrethroid formulations available commercially.

\section{Conclusion}

Present study reported the $96 \mathrm{hrs} \mathrm{LC}_{50}$ of analytical grade $\lambda$-cyhalothrin chemical in Labeo rohita fingerlings as $2.72 \mathrm{ug} / \mathrm{L}$. This chemical also caused aberrant swimming behavior in fish which suggested that $\lambda$-cyhalothrin is highly toxic to fish.

\section{Authors' contributions}

The present study was part of PDG's PhD dissertation. RSB and HSB designed the experiments. AD approved the experimental protocol. PDG drafted the manuscript and RSB critically reviewed the manuscript. AD provided critical suggestions in conducting the experiment. All authors read and approved the final manuscript.

\section{Acknowledgements}

The authors are thankful to Director of research, Guru Angad Dev Veterinary and Animal Sciences University (GADVASU) and Dean, College of Veterinary Science, GADVASU for providing facilities and funds for the research. The first author is thankful to GADVASU for providing merit scholarship during the research.

\section{Competing interests}

The authors declare that they have no competing interests.

\section{References}

1. Thatheyus, A.J. and Selvam A.D.G. (2013) Synthetic pyrethroids: toxicity and biodegradation. Applied Ecology and Environmental Sciences, 1(3): 33-36.

2. Dahamna, S., Belguet, A., Bouamra, D., Guendouz, A., Mergham, M. and Harzallah D. (2011) Evaluation of the toxicity of cypermethrin pesticide on organs weight loss and some biochemical and histological parameters. Commun. Agric. Appl. Biol. Sci., 76(4):915-921.

3. Beenakumari, Madan, V.K. and Kathpal, T.S. (2007) Pesticide residues in rainwater from Hisar, India. Environ. Monit. Assess., 133:467-471.

4. Guner, U. (2009) Determination of lambda cyhalotrin (Tekvando 5 EC) 96 hour lethal concentration 50 at Gambusia affinis (Baird \& Girard, 1853). Journal of Fisheries Sciences.com, 3(3): 214-219.

5. Lawler, S.P., Dritz, D.A. and Godfrey, L.D. (2003) Effects of the agricultural insecticide lambda-cyhalothrin (Warrior ${ }^{\mathrm{TM}}$ ) on mosquito fish (Gambusia affinis). J. Am. Mosq. Control. Assoc., 19:430-432.

6. Food and Agriculture Organization of the United Nations (FAO) (2012). The state of world fisheries and aquaculture. Rome, 2012: 230.

7. American Public Health Association (APHA) (1985) Standard methods for the examination of water and wastewater. 16th edn. Washington, USA. 1268.

8. Kumar, A., Sharma, B. and Pandey, R. S. (2010) Toxicological assessment of pyrethroid insecticides with special reference to cypermethrin and $\lambda$-cyhalothrin in freshwater fishes. Int. J. Bio. Med. Res., 1(4): 315-325.

9. Kumar, A., Sharma, B. and Pandey, R. S. (2011) Assessment of acute toxicity of k-cyhalothrin to a freshwater catfish, Clarias batrachus. Environ. Chem. Lett., 9: 43-46.

10. Kumar, A., Sharma, B. and Pandey, R. S. (2007) Preliminary evaluation of the acute toxicity of cypermethrin and lambdacyhalothrin to Channa punctatus. Bull. Environ. Contam. Toxicol., 79: 613-616.

11. Paul E. A. and Simonin H. A. (2006) Toxicity of three mosquito insecticides to crayfish. Bull. Environ. Contam. Toxicol., 76: 614-621.

12. Narahashi, T., Ginsburg, K. S., Nagata, K., Song, J. H., Tatebayashi, H. (1998) Ion channels as targets for insecticides. Neurotoxicol., 19: 581-590.

13. Yang, W.C., Gan, J.Y., Hunter, W. and Spurlock, F. (2006) Effect of suspended solids on bioavailability of pyrethroid insecticides. Environ. Toxicol. Chem., 25:1585-1591. 